\title{
Review
}

\section{The role of forest trees and their mycorrhizal fungi in carbonate rock weathering and its significance for global carbon cycling}

\author{
Rachel M. S. Thorley ${ }^{1}$, Lyla L. Taylor ${ }^{1}$, Steve A. Banwart ${ }^{2}$, Jonathan R. Leake ${ }^{1}$ \& David J. Beerling ${ }^{1}$ \\ ${ }^{1}$ Department of Animal and Plant Sciences, University of Sheffield, Sheffield S10 2TN, UK ${ }^{2}$ Kroto Research Institute, University \\ of Sheffield - North Campus, Sheffield S3 $7 H Q$, UK
}

\begin{abstract}
On million-year timescales, carbonate rock weathering exerts no net effect on atmospheric $\mathrm{CO}_{2}$ concentration. However, on timescales of decades-to-centuries, it can contribute to sequestration of anthropogenic $\mathrm{CO}_{2}$ and increase land-ocean alkalinity flux, counteracting ocean acidification. Historical evidence indicates this flux is sensitive to land use change, and recent experimental evidence suggests that trees and their associated soil microbial communities are major drivers of continental mineral weathering. Here, we review key physical and chemical mechanisms by which the symbiotic mycorrhizal fungi of forest tree roots potentially enhance carbonate rock weathering. Evidence from our ongoing field study at the UK's national pinetum confirms increased weathering of carbonate rocks by a wide range of gymnosperm and angiosperm tree species that form arbuscular (AM) or ectomycorrhizal (EM) fungal partnerships. We demonstrate that calcite-containing rock grains under EM tree species weather significantly faster than those under AM trees, an effect linked to greater soil acidification by EM trees. Weathering and corresponding alkalinity export are likely to increase with rising atmospheric $\mathrm{CO}_{2}$ and associated climate change. Our analyses suggest that strategic planting of fast-growing EM angiosperm taxa on calcite- and dolomite-rich terrain might accelerate the transient sink for atmospheric $\mathrm{CO}_{2}$ and slow rates of ocean acidification.
\end{abstract}

Key-words: alkalinity; arbuscular mycorrhiza; chemical weathering; climate change; ectomycorrhiza; soil carbonates; soil $\mathrm{pH}$.

\section{INTRODUCTION}

Fossil fuel burning and deforestation have increased the global atmospheric $\mathrm{CO}_{2}$ concentration by ca. $40 \%$ over the past century, an increase of approximately $120 \mathrm{ppm}$ (IPCC 2014). In May 2013, the atmospheric $\mathrm{CO}_{2}$ concentration measured at Mauna Loa reached 400 ppm (Tans \& Keeling 2013), which is probably the highest value for the past 10-20 million years (Beerling \& Royer 2011). Planetary surface

Correspondence: R. M. S. Thorley.e-mail: rachel.thorley@sheffield .ac.uk temperatures are responding to the increased radiative forcing from the accumulation of greenhouse gases, with each of the last three decades warmer than any other decade since 1950 (IPCC 2013). Over a timescale of decades-to-centuries, the atmospheric $\mathrm{CO}_{2}$ concentration is largely regulated by carbon exchanges between the surface carbon reservoirs of the terrestrial biosphere, surface oceans and atmosphere (IPCC 2013). Longer term regulation of atmospheric $\mathrm{CO}_{2}$ is dominated by the balance between its consumption through rock weathering and release by volcanic degassing (Berner 2003). Although the breakdown of silicate and carbonate rocks are generally regarded as slow processes, recent observational evidence (Gislason et al. 2009) and regional-scale modelling (Beaulieu et al. 2010, 2012; Goll et al. 2014) indicate that $\mathrm{CO}_{2}$-driven climate change may impact on weathering over timescales as short as decades. Weathering rates of carbonate minerals may be particularly sensitive to contemporary climate change (Beaulieu et al. 2012), providing a net sink for atmospheric $\mathrm{CO}_{2}$ on a decadal-to-century timescale, and a source of continental alkalinity to the surface oceans.

Carbonate lithology ( $\left.>80 \% \mathrm{CaCO}_{3}\right)$ occupies $10.4 \%$ of earth's continental surface (Dürr et al. 2005) and significant quantities of carbonates are also contained within a variety of sedimentary and silicate lithologies (Hartmann et al. 2009). Extensive areas of temperate and boreal forest ecosystems are underlain by carbonate lithologies, which occupy large regions in the Northern Hemisphere between $15-65^{\circ} \mathrm{N}$ (Fig. 1a,b; Amiotte-Suchet et al. 2003; Dürr et al. 2005; USGS 2008; Williams \& Fong 2010).

However, we know little about the interactions between the roots and symbiotic fungi of $\mathrm{N}$. Hemisphere forests and carbonate rocks. This is despite these regions being particularly important for weathering as, in contrast to the deeply weathered acidic soils of the forested regions of the humid tropics, the soils are often young, developing on fresh regolith deposited at the end of the last glaciation. Their contribution to alkalinity and base cation flux to the oceans will be sensitive to changes in weathering rates, to a much greater extent than older, highly weathered and base-depleted soils. For silicate rocks, it is increasingly well established that rootassociated mycorrhizal fungi are the main biotic drivers of rock weathering in soil. These fungi utilize energy from plant photosynthates to grow, proliferate and actively dissolve soil 
(a)

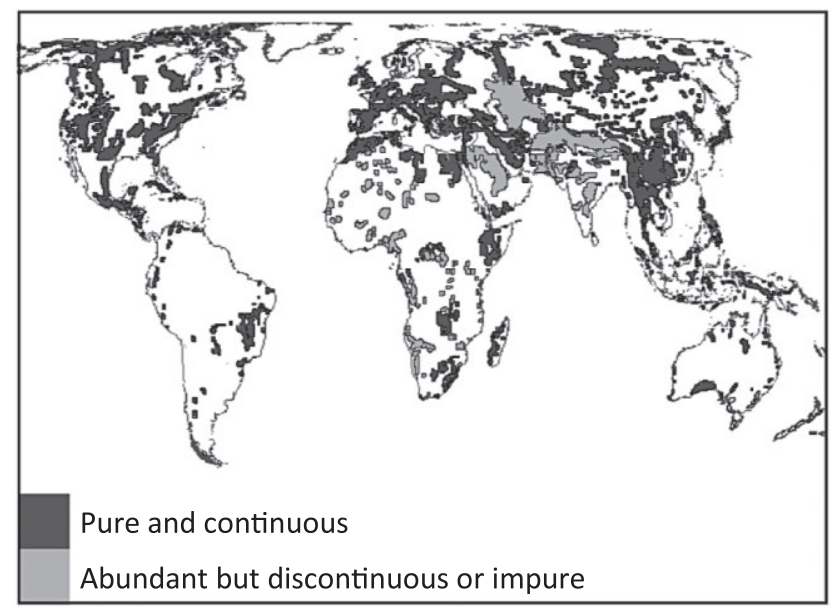

(b)

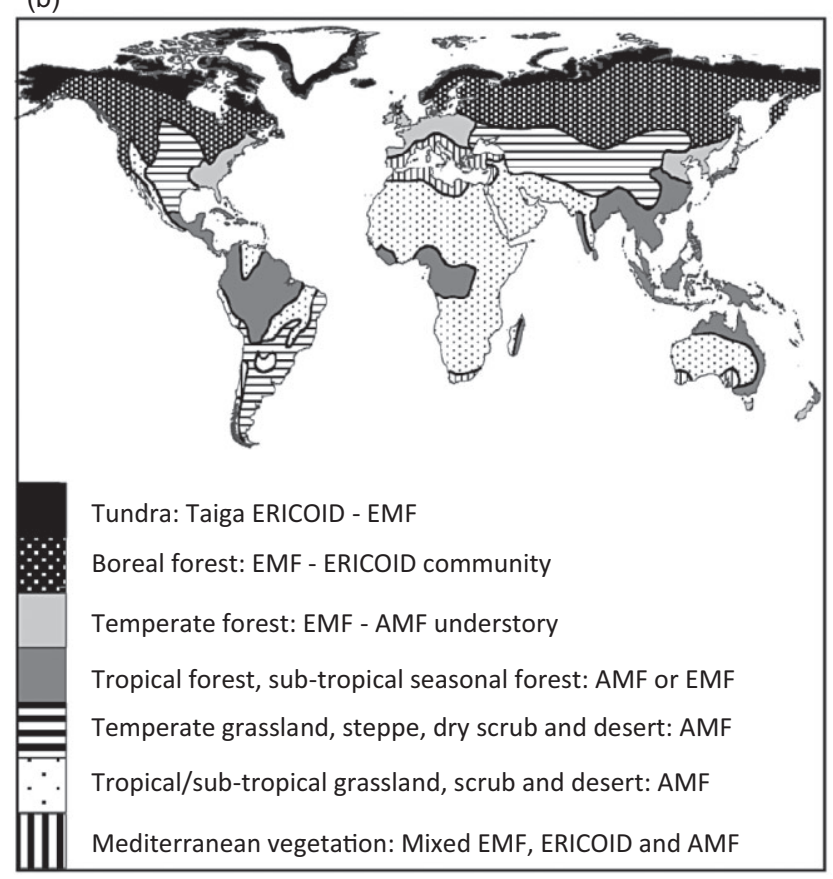

Figure 1. Global distribution of (a) carbonate rock outcrops (Williams \& Fong 2010), (b) major tree-mycorrhizal functional groups (Read 1991; Read et al. 2004).

minerals by localized mycorrhizosphere acidification (Casarin et al. 2003; Rosling 2003; Rosling et al. 2004b; van Scholl et al. 2006b). Both of the dominant mycorrhizal functional groups, arbuscular mycorrhizal (AM) and ectomycorrhizal (EM) fungi, are implicated in rock weathering (Koele et al. 2014), and actively target the weathering of particular rocks (Leake et al. 2008; Quirk et al. 2012). Hyphae preferentially colonize minerals like apatite that are sources of inorganic nutrients such as phosphorus, that limit plant growth, and in the process, release calcium and other bases (Blum et al. 2002; Hoffland et al. 2003; Smits et al. 2012). For example, in the Hubbard Brook forest watershed, the weathering of apatite present in the soil has been an important source of alkalinity and calcium ions (Blum et al. 2002). This evidence suggests that although little is known about effects of mycorrhizal fungi in relation to carbonate rock weathering rates, they are likely to be important players in this process.

The aims of this paper are threefold. Firstly, we provide an overview of the role and importance of carbonate mineral dissolution in global carbon cycling and effects of recent land use changes on land-ocean alkalinity fluxes. Secondly, we synthesize evidence for the key mechanisms by which trees and their root-associated AM and EM fungi accelerate the weathering of carbonate rocks. Thirdly, we report results from an extensive field trial designed to investigate the effect of different tree-mycorrhizal functional types on carbonate rock weathering rates. Our field trials include the four major types of carbonate rocks, chalk, limestone, marble and dolomite that underlie Northern Hemisphere forests (Fig. 1a,b). We investigated weathering under a wide variety of mature AM and EM angiosperm and gymnosperm tree species under a common climate and soil at the UK National Pinetum, Kent. Our findings are discussed in relation to the potential contribution of forest ecosystems and plantations to enhance weathering of continental carbonate minerals as part of a wider strategy to promote sequestration of atmospheric $\mathrm{CO}_{2}$ and reduce the rate of surface ocean acidification.

\section{CARBONATE ROCK WEATHERING, GLOBAL CARBON CYCLING AND LAND USE CHANGE}

Continental weathering of both carbonate and silicate minerals plays a key role in both the long-term and short-term global carbon cycles and in soil formation. Over millions of years, weathering of silicate minerals regulates the long-term sink for atmospheric $\mathrm{CO}_{2}$, and therefore climate, as $\mathrm{Ca}^{2+}$ and $\mathrm{Mg}^{2+}$ ions released from the continents lead to carbonate deposition in the oceans. In contrast, carbonate rock weathering by forested ecosystems is inconsequential for global atmospheric $\mathrm{CO}_{2}$ concentration on a multimillion year timescale due to the stoichiometry of the reactions. The $\mathrm{CO}_{2}$ consumed during weathering is balanced by its release back into the atmosphere over $>10^{4}$ years during marine calcite precipitation (Berner 1992; Liu et al. 2011; Zeebe 2012). Generalized weathering reactions for the two main types of carbonate minerals, calcite (Eqn 1) and dolomite (Eqn 2), are given by

$$
\begin{aligned}
& \mathrm{CaCO}_{3}+\mathrm{CO}_{2}+\mathrm{H}_{2} \mathrm{O} \leftrightarrow \mathrm{Ca}^{2+}+2 \mathrm{HCO}_{3}^{-} \\
& \mathrm{CaMg}\left(\mathrm{CO}_{3}\right)_{2}+2 \mathrm{CO}_{2}+2 \mathrm{H}_{2} \mathrm{O} \leftrightarrow \mathrm{Ca}^{2+}+\mathrm{Mg}^{2+}+4 \mathrm{HCO}_{3}^{-}
\end{aligned}
$$

Over short timescales of decades-to-millennia, however, carbonate weathering could act as a transient sink for anthropogenic $\mathrm{CO}_{2}$ and, through land-ocean transport of weathering products, provide a source of alkalinity to the oceans. The $\mathrm{CO}_{2}$ sink from carbonate dissolution occurs when the rates of the forward and backward reactions in Eqn 1 are unbalanced (Berner et al. 1983) and carbonate dissolution on the continents outweighs carbonate deposition in the oceans. This may occur, for example, during the enhanced carbonate weathering predicted in response to 
climate warming from a rising atmospheric $\mathrm{CO}_{2}$ concentration. The duration of $\mathrm{CO}_{2}$ sequestration may be as short as 10000 years (Zeebe 2012), and depends mainly on the residence time of ions in the oceans. For $\mathrm{HCO}_{3}^{-}$, this is roughly 100000 years; for $\mathrm{Ca}^{2+} 750000-1200000$ years and for $\mathrm{Mg}^{2+}>4$ million years (calculated after Berner et al. 1983; Li 1982; Ronov 1968). Over geological timescales, far longer than those relevant for the current study, calcite precipitation in the oceans from carbonate derived $\mathrm{Ca}^{2+}$ and $\mathrm{Mg}^{2+}$ cations re-releases $\mathrm{CO}_{2}$ and is assumed to balance continental carbonate weathering flux (Eqn 3). Currently, carbonate rock weathering sequesters up to $0.15 \mathrm{Gt} C$ per year for the duration that $\mathrm{Ca}^{2+}$ ions remain in solution with bicarbonate, $\mathrm{HCO}_{3}^{-}$(Hartmann et al. 2013). This equates to half of the total $0.288 \mathrm{Gt} \mathrm{C}$ sink from both carbonate and silicate weathering annually (Gaillardet et al. 1999).

$$
\mathrm{Ca}^{2+}+2 \mathrm{HCO}_{3}^{-} \leftrightarrow \mathrm{CaCO}_{3}+\mathrm{CO}_{2}+\mathrm{H}_{2} \mathrm{O}
$$

Carbonate rocks weather an order of magnitude faster than silicate rocks and are responsible for 34-68\% of net $\mathrm{CO}_{2}$ consumption by global-scale continental weathering (Berner et al. 1983; Gaillardet et al. 1999; Amiotte-Suchet et al. 2003; Hartmann et al. 2009). Carbonate weathering also provides a vast supply of riverine alkalinity to the oceans. The total flux of dissolved solids originating from land-ocean carbonate weathering is estimated to range from $588 \times 10^{6} \mathrm{tyear}^{-1}$ to $640 \times 10^{6} \mathrm{t} \mathrm{year}^{-1}$ (Gaillardet et al. 1999; Hartmann et al. 2014), although there are still large uncertainties relating to the behaviour of highly active weathering hotspots, and to the strong dependence of carbonate weathering rates on runoff and discharge patterns. Enhanced carbonate rock weathering in response to a warmer climate will drive an increased land-ocean flux of major ions, notably $\mathrm{Ca}^{2+}$ and $\mathrm{CO}_{3}^{2-}$ (Zeebe 2012). This enhanced alkalinity flux might partially counteract high $\mathrm{CO}_{2}$-related ocean acidification by increasing carbonate mineral saturation state and raising surface ocean $\mathrm{pH}$.

Historical studies indicate land use change is a critical factor determining rates of alkalinity fluxes to the oceans. Agricultural practices and land use change cause ecosystem disturbance altering soil hydrology and leading to increased runoff and river discharge from agricultural land (Raymond \& Cole 2003; Raymond et al. 2008). In North America, fluxes of elements such as $\mathrm{Ca}$ are higher from agricultural watersheds in both the upper Mississippi and Ohio River catchments, than from areas with natural vegetation cover, as a result of increased leaching. This is demonstrated in the United States, where conversion of forests to agricultural land has been linked to a dramatic $60 \%$ increase in the flux of carbonate alkalinity $\left(\mathrm{HCO}_{3}^{-}+\mathrm{CO}_{3}^{2-}\right)$ exported to the ocean from the Mississippi basin in the last 50 years (1954-2001) as a result of both increased run-off and addition of agricultural lime (Raymond \& Cole 2003). However, these increased fluxes of alkalinity and associated nutrients such as nitrate and phosphate have severely disrupted the ecology of the Gulf of Mexico where extreme eutrophication has developed, leading to anoxic 'dead zones' that spread up to
$15000 \mathrm{~km}^{2}$ (Diaz \& Rosenberg 2008). Here, subsurface ocean acidity is increased and biogenenic carbonate formation inhibited (Cai et al. 2011).

Furthermore, under circumstances such as these, carbonate weathering may be a net source of $\mathrm{CO}_{2}$ if weathered by an agent not derived from atmospheric $\mathrm{CO}_{2}$, including nitric and sulphuric acids derived from anthropogenic atmospheric pollution or from nitrogen fertilizers (Perrin et al. 2008; Hartmann et al. 2013). Additions of nitrogen fertilizers and manures leading to nitrate formation by nitrification processes in the soil, produces nitric acid $\left(\mathrm{HNO}_{3}\right)$, which can cause substitution of $\mathrm{CO}_{2}$-derived carbonic acid for protons from $\mathrm{HNO}_{3}$ (Eqn 4).

$\mathrm{CaCO}_{3}+\mathrm{HNO}_{3}+\mathrm{H}_{2} \mathrm{O} \rightarrow \mathrm{Ca}^{2+}+\mathrm{HCO}_{3}^{-}+\mathrm{NO}_{3}^{-}$
$\mathrm{CaCO}_{3}+2 \mathrm{HNO}_{3} \rightarrow \mathrm{Ca}^{2+}+2 \mathrm{NO}_{3}^{-}+\mathrm{CO}_{2}+\mathrm{H}_{2} \mathrm{O}$

This practice has produced a deficit in the contribution of atmospheric $\mathrm{CO}_{2}$ and soil $\mathrm{CO}_{2}$ to river alkalinity of $7-17 \%$ over 30 years in 25 agricultural catchments in the Gascogne region of France underlain by carbonate lithologies (Perrin et al. 2008). Globally, such a decrease represents an estimated $1.6-3.8 \%$ reduction in $\mathrm{CO}_{2}$ uptake by carbonate weathering and $2-5 \%$ from silicate weathering, and may counterbalance these natural weathering $\mathrm{CO}_{2}$ sinks. Effects of anthropogenic acids on carbonate weathering as a $\mathrm{CO}_{2}$ source are even more dramatic in agricultural areas that are concurrently limed and fertilized. This is estimated to release up to $3.35 \mathrm{Tg}$ year $^{-1} \mathrm{CO}_{2}$ in the United States (West \& McBride 2005).

Liming has been used as a strategy to replenish lost calcium, ameliorate surface and ground water acidity and associated aluminium toxicity, to enhance agricultural production and to rejuvenate forests damaged by acid rain in some European and North American regions (Blum et al. 2002). Lime is typically added to acid forest soils in the form of calcite or dolomite, and can result in substantially increased carbonate weathering rates (Eqn 1) and subsequent riverine fluxes of carbonate alkalinity $\left(\mathrm{CO}_{3}^{2-}\right.$, $\left.\mathrm{HCO}_{3}^{-}\right), \mathrm{Ca}^{2+}$ and $\mathrm{Mg}^{2+}$.

If the primary reason for forest liming is to combat acidic pollution by sulphuric or nitric acids, then weathering of additional carbonates may not be a $\mathrm{CO}_{2}$ sink, even if it does improve stream water quality. This parallels the situation with nitrate fertilizer application, as the weathering agent is not derived from atmospheric $\mathrm{CO}_{2}$ (Eqn 4). Observations in experimental Norway spruce plots in Höglwald Forest, Germany indicate that liming may cause a shift in mycorrhizal community to species with a preference for higher $\mathrm{pH}$, or better calcium tolerance (Nowotny et al. 1998). Whether these species achieve tolerance through increasing mycorrhizosphere acidification and therefore, carbonate weathering, is uncertain. Since forests and their associated mycorrhizal fungi are key drivers of mineral weathering (Landeweert et al. 2001; Taylor et al. 2009), any changes in tree growth and associated soil communities are likely to result in changes to weathering rates, however, this is poorly 
documented and should be an area for future forestry research.

Anthropogenic disruption of weathering processes is not limited to forests and agricultural land, but is also occurring in urban soils. In this case, however, human activity may have provided a new $\mathrm{CO}_{2}$ sink, through enhancing carbonate sequestration via the carbonation of industrial waste materials. An estimated 7-17 billion tonnes of artificial silicate waste materials are produced annually, with the potential to sequester 190-332 million tonnes urban C through precipitation of pedogenic carbonates reacting with oxides in cements and building rubble (Renforth et al. 2011). This is a process that reverses the loss of $\mathrm{CO}_{2}$ to the atmosphere that occurs as limestone is burned to produce cement (Renforth et al. 2011; Manning \& Renforth 2013), but does not reverse the $\mathrm{CO}_{2}$ loss associated with the fossil fuel used in making cement. Studies at one brownfield site in Newcastle and former steelworks in Consett, NE England, have shown that carbonation sequesters about $25 \pm 12.8 \mathrm{t} \mathrm{C} \mathrm{ha}^{-1}$ year $^{-1}$ (Renforth et al. 2009). In urban brownfield sites, carbonation of industrial waste materials is primarily an abiotic process. However, vegetation planting at these sites would be likely to further increase carbonation rate by increasing soil $\mathrm{CO}_{2}$ concentrations, which in these carbon sequestering soils, might be rate limiting (Renforth et al. 2011; Manning \& Renforth 2013).

\section{MECHANISMS OF CARBONATE WEATHERING BY TREE-MYCORRHIZAL PARTNERSHIPS}

Mechanisms of mineral weathering by both AM and EM fungi have been reviewed recently in relation to silicate weathering (Rosling et al. 2004a; Wallander \& Thelin 2008; Taylor et al. 2009; Brantley et al. 2011). In this section, we highlight three key weathering strategies of mycorrhizal fungi with special emphasis on how they relate to carbonate rocks. (1) Physical weathering by mycorrhizal hyphae penetrating or trenching minerals; (2) chemical weathering by secreted organic acids and chelating cations that acidify the rhizosphere and complex metal cations; and (3) action of respiratory $\mathrm{CO}_{2}$-derived carbonic acid, and the mycorrhizal secretion of carbonic anhydrase, an enzyme that catalyses production of this acid.

\section{Physical weathering by mycorrhizal hyphae}

Both AM and EM fungi radiate from host plant root tips through the soil forming networks of hyphae whose active growing tips proliferate when they encounter rock and mineral particles containing particular elements or minerals (Leake et al. 2008). The narrow, 3-10 $\mu \mathrm{m}$ diameter, hyphae of EM fungi can trace the contours of rock particle surfaces, following scratches or ridges and entering rock pores and fissures (reviewed in Hoffland et al. 2003; Landeweert et al. 2001). Fungal hyphae strongly adhere to mineral surfaces and exert forces, using high turgor pressures. Hyphae can widen existing fissures and grow between mineral cleavage planes and within spaces in the rock.
Hyphae can produce channels and trenches on carbonate minerals, for example on polished marble after 4 months colonization by Heboloma crustaliniforme ectomycorrhizal with Pinus sylvestris (Rosling 2003). Channels have also been seen on a variety of silicate minerals under both AM and EM forests (Hoffland et al. 2003; Smits et al. 2005; Quirk et al. 2012; Koele et al. 2014); on chlorite and biotite in microcosms containing EM tree seedlings in symbiosis with Paxillus involutus (Bonneville et al. 2009; Gazzè et al. 2012), and on biotite flakes incubated in a liquid culture with EM Suillis tomentosus (Balogh-Brunstad et al. 2008). A recent field study with a limited range of species suggests that the magnitude of mineral weathering and trenching is greater under EM tree species than under AM tree species (Quirk et al. 2012). Fungi can tunnel into rocks (Hoffland et al. 2003; Hoppert et al. 2004; Smits et al. 2005; Koele et al. 2014), and there are reports of limestone colonized by an endolithic lichen in which the fungal and algal partners live inside the rock (Hoppert et al. 2004). However, fungal tunnelling appears to be slow and contributes only modestly to weathering, accounting for around than $2 \%$ of total feldspar weathering in a temperate coniferous forest (Smits et al. 2005).

Few quantitative experiments have determined the contribution of physical hyphal contact to carbonate mineral weathering. Li et al. (2009) used liquid culture experiments, and incubated limestone granules with a saprotrophic Penicillium fungus for $25 \mathrm{~h}$, and calculated dissolution rates from measurements of $\mathrm{pH}$ and $\mathrm{Ca}^{2+}$ concentration. Limestone dissolution was reduced by $22 \%$ when the grains were separated from the culture by a fine mesh to exclude Penicillium spp. hyphae. Fungal growth in liquid media is often very different to that on complex media like soil and minerals so that extrapolation from such experiments to field relevance presents significant challenges.

\section{Chemical weathering by organic acids and anions}

Low molecular weight organic acids (LMWOAs) are potentially the most important biological weathering agent in soil (reviewed in Landeweert et al. 2001) because carbonate minerals are highly susceptible to acid dissolution. LMWOAs secreted by plants, fungi and other microorganisms are involved in metal detoxification and mineral dissolution in soils, enlarging and merging surface enlarging and merging surface scratches and linear pits developed through cleavage of minerals for experimental studies (Gazzè et al. 2012). LMWOAs are more important than carbonic acid for weathering of carbonates. For example, Penicillium spp. grown in liquid culture showed greater reduction in carbonate rock dissolution when organic acids were neutralized using $\mathrm{NaOH}$ than when acetazolamide inhibited carbonic anhydrase activity thus severely inhibiting carbonic acid production (Li et al. 2009).

LMWOAs, however, form only a minor component of the total complement of organic acids in soil and have a fast turnover rate, being rapidly biodegraded or precipitated in complexes and adsorbed to soil particles (van Hees et al. 
2002). LMWOAs combine soil solution acidification, via proton release, with the ion-complexing capacity of chelating anions. Chelating species such as LMWO anions have several delocalized negative charges spread across the anion and can surround a small charge-dense cation forming several ionic bonds. Chelation occurs when bonding between the chelating anion and metal cation is stronger than the interaction between the cation and its mineral substrate. Oxalic acid can facilitate carbonate dissolution through forming complexes with both $\mathrm{Ca}$ and $\mathrm{Mg}$ ions, in addition to a range of other ions such as $\mathrm{K}, \mathrm{Mn}, \mathrm{Zn}, \mathrm{Cu}, \mathrm{Al}$ and $\mathrm{Fe}$ from silicate substrates (Landeweert et al. 2001). EM fungi secrete a range of mono-, di- and tri-carboxylic acids, including oxalic, malic and citric acid, dependant on fungal species (Arvieu et al. 2003; van Scholl et al. 2006a). AM fungi are generally considered to not produce LMWOAs, but a recent study with AM clover plants identified formate and acetate in culture medium surrounding AM mycelium (Toljander et al. 2007). However, these monocarboxylates have very limited complexation abilities compared to the di- and tri-carboxylic acids released by EM fungi.

Although in bulk soil solution LMWOAs concentrations are likely to be too low to exert major mineral weathering effects, where roots and mycorrhizal hyphae establish intimate contact with minerals, they may be able to generate sufficiently high concentrations to significantly promote chemical weathering. Typical concentrations range from $<0.1-17 \mu \mathrm{M}$ in the field and $<0.1-2.3 \mu \mathrm{M}$ in laboratory pot experiments (van Hees et al. 2002, 2003). The most important dissolution mechanisms of LMWOAs are targeted, local rhizosphere acidification and formation of a layer of organic exudates known as a biofilm (Saccone et al. 2012). The range of acids differs between both tree species and mycorrhizal association and include oxalic, citric, butyric, formic, phthalic, malonic, succinic, lactic and tartaric acids (Arvieu et al. 2003; Casarin et al. 2003; Sandnes et al. 2005). Oxalate is probably the most important LMWOA for carbonate dissolution (Gadd \& Poole 1999). It is typically secreted at higher rates than other minor LMWOAs, and its release is coupled to soil acidification by $\mathrm{H}^{+}$. The coupling of oxalate secretion and mycorrhizosphere acidification is suggested by the correlation of oxalate concentration and $\mathrm{pH}$ in liquid culture experiments (Arvieu et al. 2003; Casarin et al. 2003), and will heighten the impact of this LMWOA on carbonate dissolution.

Many EM fungi produce low molecular weight, ironchelating ligands called siderophores (Szaniszlo et al. 1981), and there are indications that the AM fungal clade Glomus may produce siderophores, but this is unproven (Haselwandter 2008). The main function of siderophores is for uptake of iron, reacting with otherwise insoluble Fe(III) to form highly stable complexes in solution (Renshaw et al. 2002). When in pure culture, mycorrhizal fungi can produce a wide range of hydroxamate siderophores in response to iron deprivation (Szaniszlo et al. 1981; Renshaw et al. 2002), an effect stimulated by $\mathrm{CaCO}_{3}$. Siderophores may be important in releasing iron from both calcite and dolomite rocks where iron is a common trace element (Scoffin 1987) and removal of
Fe might facilitate weathering by altering the structural integrity of such rocks. This weathering may be important in calcareous soils where $\mathrm{Fe}(\mathrm{III})$ is virtually insoluble, often limiting plant and fungal growth, as evidenced by limeinduced iron chlorosis (Marschner 1995).

\section{Rhizosphere acidification by respiratory $\mathrm{CO}_{2}$ production and carbonic anhydrase}

Both EM and AM fungi may promote carbonate mineral weathering by acidifying the soil solution through proton extrusion associated with cation uptake (Koele et al. 2014). Soil respiration and $\mathrm{CO}_{2}$ production by mycorrhizal fungi result in a weakly acidic solution of carbonic acid (Eqn 5), a reaction that can be up-regulated by the action of carbonic anhydrase (CA) enzyme.

$\mathrm{CO}_{2}+\mathrm{H}_{2} \mathrm{O} \leftrightarrow \mathrm{H}_{2} \mathrm{CO}_{3} \leftrightarrow \mathrm{HCO}_{3}^{-}+\mathrm{H}^{+}$

$\mathrm{CA}$ catalyses the conversion of soil $\mathrm{CO}_{2}$ into carbonic acid (Eqn 5), which is the primary abiotic weathering agent of soil minerals. This reaction occurs slowly at ambient $\mathrm{CO}_{2}$ partial pressures found in the environment and is often the rate-limiting stage in limestone dissolution (Liu et al. 2005). Genes for CA synthesis are expressed in EM fungi (reviewed in Landeweert et al. 2001) and have also been identified in AM fungi (Tisserant et al. 2012). Carbonic anhydrase activity accelerates carbonate dissolution through coupled weathering reactions, so long as reaction endproducts continue to be removed through soil drainage (Lian et al. 2011). In a closed system starting far from equilibrium, CA addition increases initial carbonate dissolution rates by up to a factor of 50, depending on rock type and grain size (Liu 2001; Liu et al. 2005). The effect of CA catalysis depends on the availability of $\mathrm{CO}_{2}$ substrate, and potentially also on the type of carbonate mineral (Liu 2001; Liu et al. 2005). Abiotic kinetic experiments tracking solution conductivity, as a proxy for dissolved $\mathrm{Ca}^{2+}$ and $\mathrm{Mg}^{2+}$, illustrated that limestone, but not dolomite, dissolution could be increased tenfold by addition of $0.2 \mu \mathrm{M}$ bovine CA, but only when solution $\mathrm{pCO}_{2}$ was greater than $100 \mathrm{~Pa}$. Soil $\mathrm{CO}_{2}$ concentration varies between ecosystems, and is typically far higher than in the laboratory experiments of Liu et al. (2005). For example, in Arctic soils, $\mathrm{pCO}_{2}$ $=7600 \mathrm{~Pa}$ (Alaska); in temperate forest soils $\mathrm{pCO}_{2}=15300$ $\mathrm{Pa}$ (Germany); and in tropical forests $\mathrm{pCO}_{2}=25500 \mathrm{~Pa}$ (Trinidad; Brook et al. 1983). At a field study at various sites across limestone areas in China, Li et al. (2005) showed that densely vegetated areas had higher microbial CA activity linked to extracellular CA production by fungi. Although no mycorrhizal fungi were explicitly identified, several plots were located within evergreen broad-leaf and needle-leaf (pine) woodland in which trees universally form mycorrhizal associations implicating the involvement of their mycorrhizal associates. This is supported by the higher soil CA activity detected in the vicinity of plant roots and the sharp decline in CA activity with depth. Further work is required to resolve the contribution of mycorrhizal fungi to 
these processes and the extent to which $\mathrm{CA}$ increases rates of carbonate weathering in forest ecosystems.

\section{EFFECT OF TREE-MYCORRHIZA FUNGAL PARTNERSHIPS ON RATES OF CARBONATE WEATHERING IN THE FIELD}

Previous work suggests that AM and EM trees are likely to enhance the weathering of carbonate minerals to differing extents through organic acid exudation and acidification of their mycorrhizospheres. We therefore undertook field trials on representative tree-mycorrhizal functional groups found on carbonate rock lithology (Fig. 1a,b) and focused on characterizing weathering within single-species stands $\left(30 \mathrm{~m}^{2}\right)$ of mature trees in a common parent soil at the UK's national pinetum in Bedgebury, Kent, UK $\left(51.07^{\circ} \mathrm{N}, 0.44^{\circ} \mathrm{E}\right)$. Replicate trees $(n=5)$ from 13 species (Table 1$)$ were selected to represent the four functional groups: AM gymnosperm, AM angiosperm, EM gymnosperm and EM angiosperm. Crushed and sieved carbonate rock samples $(2.5 \mathrm{~g}$ with a particle size of $0.5-1.18 \mathrm{~mm}$ diameter) were buried in hyphal in-growth bags ( $n=5$ bags per rock per species) planted at $10 \mathrm{~cm}$ depth ca. $1 \mathrm{~m}$ from the base of each tree. We investigated four carbonate rock types: (1) marble (Carrara, Italy); (2) oolitic limestone (Oxfordian, N. Yorkshire); (3) chalk (Cretaceous, N. Yorkshire); and (4) dolomite (Permian, Doncaster) that span the entire range of carbonate lithologies beneath $\mathrm{N}$. Hemisphere forests. For comparison, we also included in-growth bags with basalt grains (Tertiary, Skye), a carbonate-containing silicate rock that has been used previously in weathering experiments involving trees and mycorrhizas (Leake et al. 2008; Quirk et al. 2012).

In the present field trials, we estimated net weathering rates by measuring mass loss of rock samples in mesh bags retrieved after 3 months burial during the active growing season (April-August 2013). For comparison between rock types, molar weathering rates were calculated, using experimentally determined rock densities and assuming spherical particle geometry. Mesh bags ( $35 \mu \mathrm{m}$ pore size) allow for exchange of substances with soil pore water and permit hyphal in-growth and colonization while excluding roots. To investigate possible linkages between mineral weathering rates and soil acidity, we collected soil samples from the surface organic-rich soil horizon near the base of each tree. Air-dried and ball-milled soil was mixed with water in a 1:1 ratio $\mathrm{v} / \mathrm{v}$ and $\mathrm{pH}$ measured using a $\mathrm{pH}$ meter (Jenway 3540 pH meter, Bibby Scientific Limited, Stone, UK; calibrated at pH 4, pH 7 and pH 10) Statistical analyses were performed using R2.14.2, in association with the R-Studio interface (www.rstudio.com 2012). Data were analysed using a variety of statistical techniques including ANOvA, and graphed using the ggplot2 package (Wickham 2009) and GraphPad Prism version 6.04 for Windows (GraphPad Software, La Jolla, CA, USA, www.graphpad.com GraphPad 2014).

After 3 months of burial (May-August 2013), rates of mass loss (i.e. net weathering) from calcite-containing rock grains in the root-excluding mesh bags were more than an order of magnitude faster than those from basalt grains (calcite average mass loss 14.0 times higher than for basalt under EM angiosperms, Fig. 2). High carbonate weathering rates are partly determined by the functional type of the tree stand, with greatest calcite-weathering rates beneath EM angiosperms (two-way ANova, $F_{1,9}=9.94, P<0.05$; Fig. 2 b). Both tree group (angiosperm/gymnosperm) and mycorrhizal type significantly affected calcite-weathering rate. However, Fig. 2 indicates that this result may be driven by the much greater 3 month weathering rates beneath EM angiosperms. Basalt and dolomite weathering was similar between treemycorrhizal functional groups, and showed no significant effect of either tree or mycorrhizal type (two-way ANOvA: basalt, $F_{1,9}=0.11, P=0.75$; dolomite, $F_{1,9}=0.89, P=0.37$; Fig. 2b).

\section{SOIL ACIDITY AS A DRIVER OF CARBONATE WEATHERING}

At our field site, Bedgebury Pinetum, soil has been developing for almost 100 years beneath the stands of mature trees

\begin{tabular}{|c|c|c|c|c|}
\hline Mycorrhiza & Tree group & $\begin{array}{l}\text { Leaf } \\
\text { habit }\end{array}$ & Species (where identified) & Family \\
\hline \multirow[t]{7}{*}{$\mathrm{AM}$} & \multirow[t]{4}{*}{ Gymnosperm } & $E$ & Ginkgo biloba & Cupressaceae \\
\hline & & $E$ & Metasequoia glyptostroboides & Cupressaceae \\
\hline & & $E$ & Sequoia sempervirens & Cupressaceae \\
\hline & & $E$ & Araucaria araucana & Araucariaceae \\
\hline & \multirow[t]{3}{*}{ Angiosperm } & $E$ & Ilex aquifolium & Aquifoliaceae \\
\hline & & $D$ & Acer pseudoplatanus & Sapindaceae \\
\hline & & $D$ & Liriodendron tulipifera & Magnoliaceae \\
\hline \multirow[t]{6}{*}{ EM } & \multirow[t]{3}{*}{ Gymnosperm } & $E$ & Pinus sylvestris & Pinaceae \\
\hline & & $D$ & Larix decidua & Pinaceae \\
\hline & & $E$ & Abies nordmanniana & Pinaceae \\
\hline & \multirow[t]{3}{*}{ Angiosperm } & $E$ & Nothofagus dombeyi & Nothofagaceae \\
\hline & & $D$ & Quercus petraea & Fagaceae \\
\hline & & $D$ & Eucalyptus coccifera & Myrtaceae \\
\hline
\end{tabular}

Table 1. Tree species used in mycorrhizal weathering field study at Bedgebury Pinetum

Tree group: gymnosperm or angiosperm; mycorrhizal type: ectomycorrhizal (EM) or arbuscular mycorrhizal (AM); leaf habit: evergreen $(E)$ or deciduous $(D)$. 


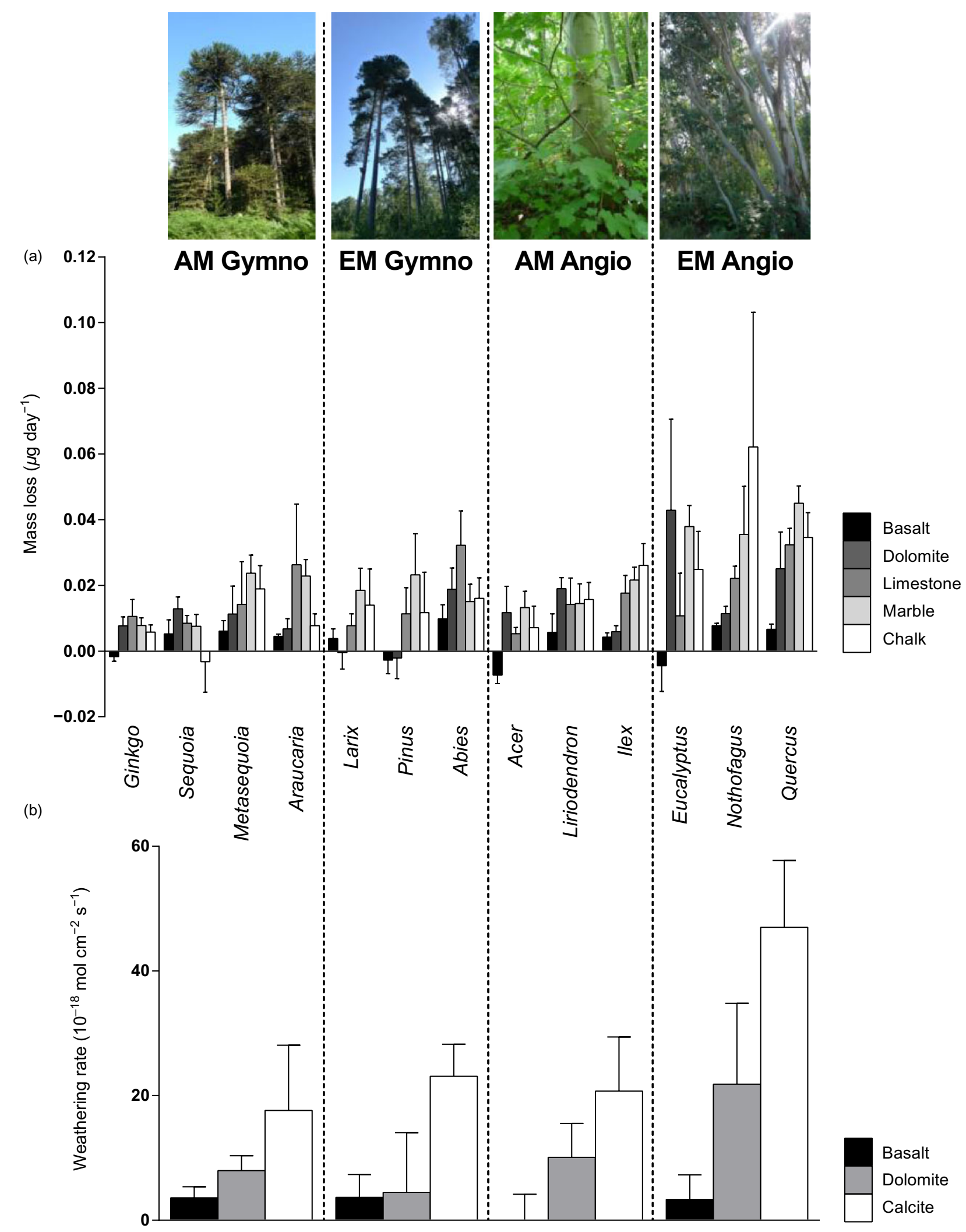

Figure 2. Weathering of rock grains buried in root-excluding mesh bags after 3 months (May-August 2013) at Bedgebury Pinetum, Kent, UK, under representative trees in established stands. Values are mean tstandard error of the mean (SEM) mass loss. Results sorted by (a) tree species ( $n=3$ replicate trees of each of 13 species, Table 1$)$ and (b) tree-mycorrhizal functional group for each calcite (chalk, oolitic limestone and marble), dolomite and basalt minerals ( $n=3$ tree species of each functional group, except arbuscular mycorrhizal (AM) gymnosperm where $n=4)$. 
selected for this study and distinct differences are evident beneath different tree species. The most acidic soils were located beneath trees forming EM partnerships $(\mathrm{pH}$ $3.50 \pm 0.04, n=6$; mean \pm standard error of the mean (SEM)). Soils beneath trees forming AM partnerships were less acidic ( $\mathrm{pH} 4.30 \pm 0.22, n=7$; mean $\pm \mathrm{SEM})$. Although mycorrhizal partnership had a significant effect on soil $\mathrm{pH}$ (AM/EM: three-way ANOvA; $F_{1,5}=8.76 ; n=13 ; P=0.032$ ), there was no effect of either tree type (angiosperm/ gymnosperm: three-way ANOvA; $F_{1,5}=0.08 ; n=13 ; P=0.79$ ) or leaf habit (evergreen/deciduous: three-way ANOvA; $\left.F_{1,5}=1.92 ; n=13 ; P=0.22\right)$. This indicates that rhizosphere acidification associated with the direct and indirect effects of mycorrhizal fungi, and especially EM fungi, may be the most important factor in determining soil $\mathrm{pH}$, and associated weathering. This contrasts with the common expectation that greater acidification occurs in conifer (gymnosperm) forest soils at Bedgebury (Ovington 1953). Soil acidification by both angiosperm and gymnosperm EM trees may be due to proton extrusion, accumulation of humus, loss of base cations through leaching and tree uptake, and the production of organic acids (Arvieu et al. 2003; Casarin et al. 2003, 2004; Sandnes et al. 2005). In our field trials, soil $\mathrm{pH}$ was one of the main drivers of calcite rock weathering (Fig. $3 ; F_{1,11}=8.17$; $\left.n=13 ; P=0.016 ; R^{2}=0.426\right)$. A similar general pattern of higher mass loss with increasingly acidic soils was also apparent for dolomite (Fig. 3b), but not significant $\left(F_{1,9}=2.52\right.$; $\left.n=11 ; \mathrm{P}=0.147 ; R^{2}=0.22\right)$.

To understand the geochemical basis for the dependency of field-observed weathering rates on soil $\mathrm{pH}$ and proton availability, field data were compared to theoretical weathering rates calculated according to Eqn 6 (Chou et al. 1989):

$$
\text { Rate }=k_{1}\left[H^{+}\right]^{s}+k_{2}\left[\mathrm{H}_{2} \mathrm{CO}_{3}\right]^{s}+k_{3}
$$

In Eqn 6, s signifies reaction order, for example, in acidic conditions, the dissolution of calcite used $s=1 . k_{1}, k_{2}, k_{3}$ are temperature-dependant rate constants for the three carbonate weathering reactions below. The relative importance of these three mechanisms depends on the soil $\mathrm{pH}$ and $\mathrm{pCO}_{2}$ environment:

$$
\begin{gathered}
\text { Acidic } \mathrm{pH}(<\mathrm{pH} 7) \text { with low } \mathrm{pCO}_{2}: \\
\mathrm{MCO}_{3}+\mathrm{H}^{+} \stackrel{k_{1}}{\rightarrow} \mathrm{M}^{2+}+\mathrm{HCO}_{3}^{-}
\end{gathered}
$$

\section{Moderate $\mathrm{pH}$ (ca. $\mathrm{pH} 7$ ) with high $\mathrm{pCO}_{2}$ :}

$$
\mathrm{MCO}_{3}+\mathrm{H}_{2} \mathrm{CO}_{3} \stackrel{k_{2}}{\rightarrow} \mathrm{M}^{2+}+2 \mathrm{HCO}_{3}^{-}
$$

$$
\begin{aligned}
& \text { High } \mathrm{pH}(>\mathrm{pH} 7) \text { with low or no } \mathrm{pCO}_{2} \text { : } \\
& \mathrm{MCO}_{3} \stackrel{k 3}{\rightarrow} \mathrm{M}^{2+}+\mathrm{CO}_{3}^{2-}
\end{aligned}
$$

Calcite, $\mathrm{CaCO}_{3}$, dissolution is first order and $s=1$, dolomite, $\mathrm{CaMg}\left(\mathrm{CO}_{3}\right)_{2}$, has a different rate dependence on $\mathrm{pH}$ and follows a fractional order when dissolving in acidic conditions, often quoted as $s=0.5$. Dolomite dissolution also has a different stoichiometry because 2 moles of acid are required to fully dissolve one mole of dolomite. The theoreti- cal weathering rate for dolomite (Fig. 3) is calculated with $s=0.75$, for comparison with the work of Chou et al. (1989). Temperature-dependant rate constants, $k_{1}, k_{2}, k_{3}$ from Chou et al. (1989) and Palandri \& Kharaka (2004) are used to calculate theoretical weathering rates, at both $25^{\circ} \mathrm{C}$ and adjusted to field air-temperature $\left(13.4{ }^{\circ} \mathrm{C}\right.$, hourly weather station data, May-August, Bedgebury Pinetum) using activation energy, $E_{\mathrm{a}}\left(\mathrm{J} \mathrm{K}^{-1} \mathrm{~mol}^{-1}\right.$; Palandri \& Kharaka 2004). When calculating the theoretical weathering rate within the $\mathrm{pH}$ range 3-6, which spans the $\mathrm{pH}$ of all soils sampled at Bedgebury Pinetum in December 2013, it was assumed that the main factor determining weathering rate is the acidic rate term, $k_{1}\left[\mathrm{H}^{+}\right]^{s}$, and the curve was calculated without taking into account the effect of $\mathrm{pCO}_{2}$, represented by the neutral term $k_{2}\left[\mathrm{H}_{2} \mathrm{CO}_{3}\right]^{s}$. This latter assumption was made as in the field soil $\mathrm{CO}_{2}$, carbonic acid and organic acid exudates all contribute to the overall, acidic, soil $\mathrm{pH}$ and inclusion of an additional $k_{2}\left[\mathrm{H}_{2} \mathrm{CO}_{3}\right]^{s}$ may result in an overestimation of theoretical weathering rate. In this study, these soil acidifying agents have not been separated, as their relative importance is likely to vary seasonally and in response to climatic conditions, changing soil hydrology and biological activity. With these assumptions, theoretical curves at $298 \mathrm{~K}$ lie close to the experimental results of Chou et al. (1989) within the $\mathrm{pH}$ range investigated in this field study. For dolomite, the theoretical curve lies slightly below the experimental results of Chou et al. (1989), and inclusion of the $k_{2}$, carbonic acid, term might improve their correspondence.

Experimental field weathering for calcite and dolomite both follow the same pattern as theoretical rate, when adjusted for particle surface area (mean diameter $=0.84 \mathrm{~mm}$ ). However, carbonate rock weathering under field conditions was several orders of magnitude slower than that expected based on rates derived from laboratory studies ( 6 for calcite-containing rocks and 2-3 for dolomite), as often observed for silicate weathering rates under field versus laboratory conditions (White \& Brantley 2003).

One factor to explain the gap between observed and theoretical dissolution is that in the field, water-mineral contact time is far lower than in laboratory studies. Low water availability, in periods with little rainfall will slow weathering as dissolved ions cannot be transported away from the weathering surface, increasing near-surface saturation and shifting the carbonate dissolution equilibrium to make dissolution less favourable. Rate constants $k_{1}, k_{2}$ and $k_{3}$ used to calculate theoretical weathering rates for calcite and dolomite are also likely to be different in the field than in the experimental closed systems used to derive these values. Secondly, the field rate constants will vary slightly depending on the precise mineral composition of the rocks weathering. Although literature estimates of these rate constants for pure minerals provide a reasonable estimate, experimental determination of $k_{1}, k_{2}$ and $k_{3}$ may improve correspondence between theoretical and field results.

The surface area vulnerable to weathering action is likely to be another factor contributing to the discrepancy between field and theoretical results. Petrological examinations show chalk, dolomite, marble and limestone have a 
(a)

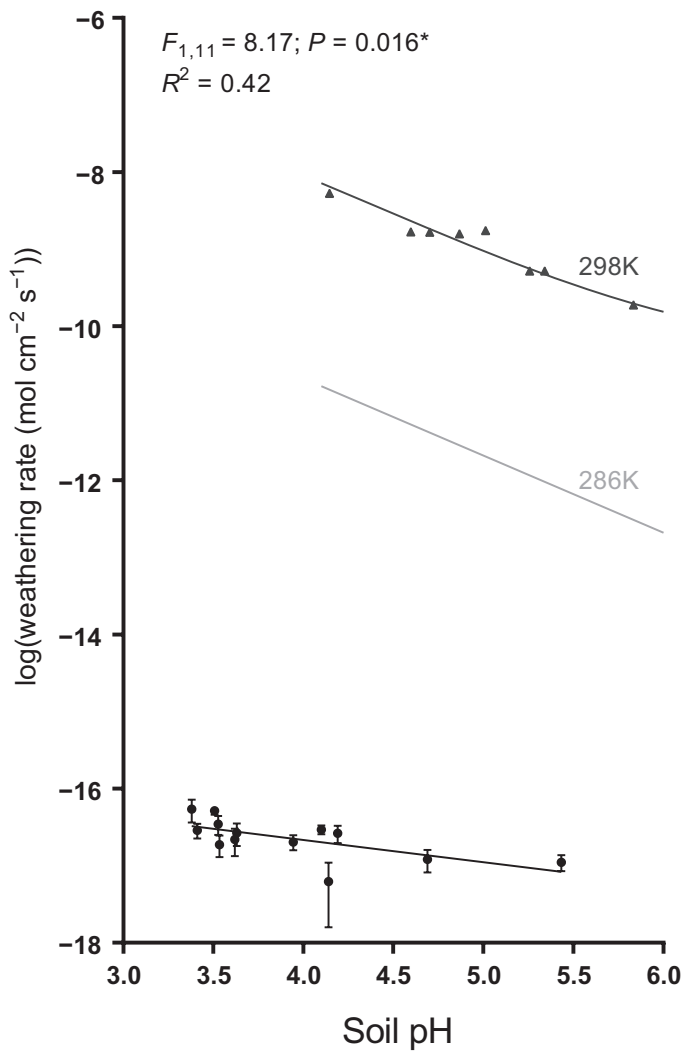

(b)

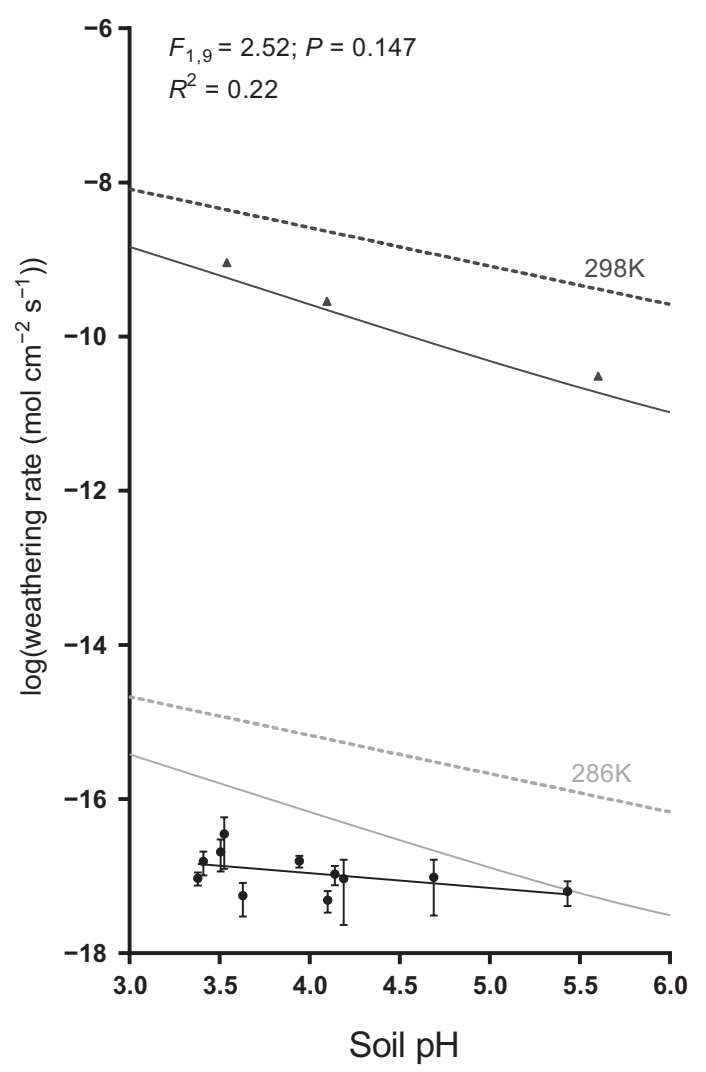

(c)

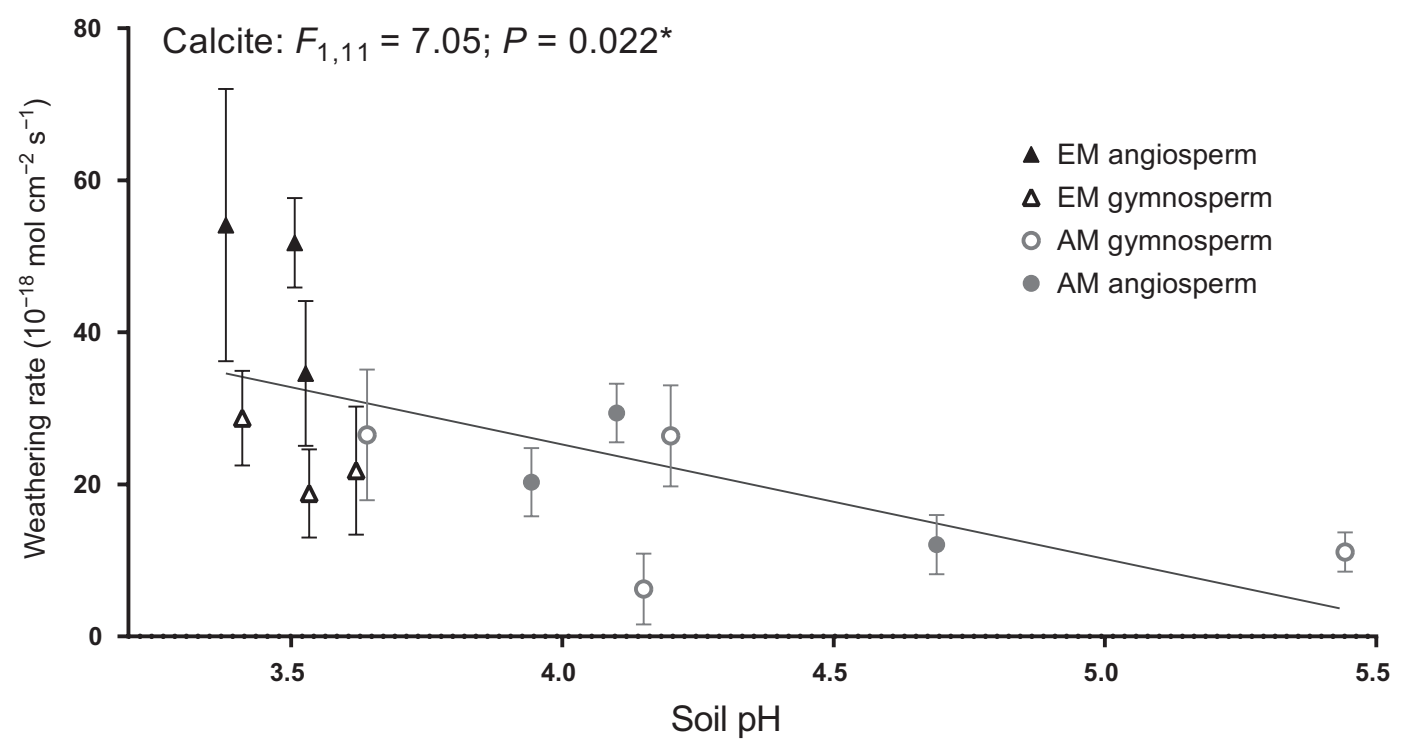

Figure 3. Effect of soil pH on field weathering rates at Bedgebury Pinetum, Kent, UK (May-August 2013). Comparison of experimental results with calculated theoretical rates at $298 \mathrm{~K}$ (dark grey lines; dark grey data points are experimental results from Chou et al. 1989 at $298 \mathrm{~K}$ ) and field temperature, $286.4 \mathrm{~K}$ (light grey lines) for (a) calcite ( $n=13$ tree species) and (b) dolomite $(n=11$ tree species), across the measured range of field soil $\mathrm{pH}$. For dolomite, dashed lines signify order of the dolomite dissolution reaction $($ Eqn 6$), s=0.5$, and solid lines represent order, $s=0.75$ as used in Chou et al. (1989). Rate constants were adjusted for $286.4 \mathrm{~K}$ using the Arrhenius equation and activation energies from Palandri \& Kharaka (2004). Outputs of two-way ANova for dependence of field weathering rate on $\mathrm{pH}$ are displayed on each graph panel. (c) Calcite field weathering rates for each tree species ( $n=13$ tree species, three replicate trees for each species) adjusted for surface area. EM angiosperm (black closed symbols); EM gymnosperm (black open symbols); AM angiosperm (grey closed symbols); AM gymnosperm (grey open symbols). 
wide range of textures and properties (Scholle \& Ulmer-Scholle 2003), and quantification of surface area and porosity for the carbonate rocks used in this experiment may help to reduce the gap between field experiment and theoretical results. Laboratory weathering rates are often normalized using BET (Brunauer-Emmett-Teller) surface area from nitrogen gas absorption measurements (Brantley \& Mellott 2000; White \& Brantley 2003; Navarre-Sitchler \& Brantley 2007), although in the current study, the surface areas of both theoretical and experimental rock grains are calculated based on spherical particles as BET values for the rocks used are not available.

\section{DIRECT EVIDENCE OF FUNGAL-CARBONATE INTERACTIONS WEATHERING}

We observed surface weathering features on dolomite grains, excavated after 3 months burial in the field, using SEM imaging (Philips XL-20 SEM, Philips, Eindhoven, Netherlands; Department of Biomedical Sciences; University of Sheffield) that avoided pretreatment before gold sputtercoating of samples. SEM imaging of grains recovered from beneath mature stands of $P$. sylvestris and Larix decidua indicate that the hyphae form a mesh-like network across the grain surface (Fig. 4a). On some grains, SEM imaging revealed a series of grooves or channels (Fig. 4b) where hyphae have either been dislodged or have deflated in situ. In Fig. 5b, the surface of the rock is more granular. Here, hyphae grow across the surface, and younger, branching, hyphae of smaller diameter appear to disappear into the rock matrix.

Evidence of hyphal channelling on the surface of carbonate rocks has been shown previously on polished marble in microcosm studies with Heboloma crustuliniforme, EM with pine seedlings (Rosling 2003). In our samples, SEM imaging revealed trenching features on dolomite along the path of a hypha that has been partially detached from the rock surface (Fig. 5c,d). The diameter of hyphae observed on rock grains in stands of both Pinus and Larix trees have a diameter of approximately $3 \mu \mathrm{m}$, within the typical range for EM hyphae (Hoffland et al. 2003) and of slightly greater width than the $2 \mu \mathrm{m}$ channel identified in Rosling (2003). Where hyphal channels were observed, the texture of the adjacent rock surface was found to be pitted. Surface etching may extend slightly beyond the area occupied by a fungal hypha, which may indicate the involvement of fungal secretions, such as organic acids (Saccone et al. 2012), in the formation of these weathering features (Fig. 5d). The degree of surface etching by hyphae might depend on rock type and surface structure at the point of hyphal adhesion, as although, in the current study, images of dolomite show clear pitting (Fig. 5d), comparison with marble (Rosling 2003) shows little surface texture modification within the hyphal channel.

Hyphae growing on carbonate rock grains are occasionally encrusted with angular crystals (Fig. 4a); due to secondary mineral formation. These crystals are likely to be calcium oxalate as recently found for EM fungal growth on a range of minerals (Schmalenberger et al. 2010). The hyphae of oxalate-producing fungi are often encrusted with $\mathrm{Ca}$-rich oxalate crystals, observed in Piloderma (Arocena et al. 2001; Casarin et al. 2003), Paxillus involutus (Lapeyrie et al. 1987) and on non-mycorrhizal fungi on weathering chalk (Verrecchia \& Dumont 1996). These distinctive crystals are formed from the weathering products of Ca-bearing soil minerals (Kolo et al. 2007).

\section{HOW MIGHT TERRESTRIAL CARBONATE WEATHERING RESPOND TO RISING $\mathrm{CO}_{2}$ AND ANTHROPOGENIC CLIMATE CHANGE?}

Our results support the expectation that trees and mycorrhizal fungi play an important role in accelerating carbonate rock weathering under field conditions. The potential sensitivity of rates of carbonate rock weathering in response to rising atmospheric $\mathrm{CO}_{2}$ concentrations and climate change has been addressed through coupled modelling of

(a)

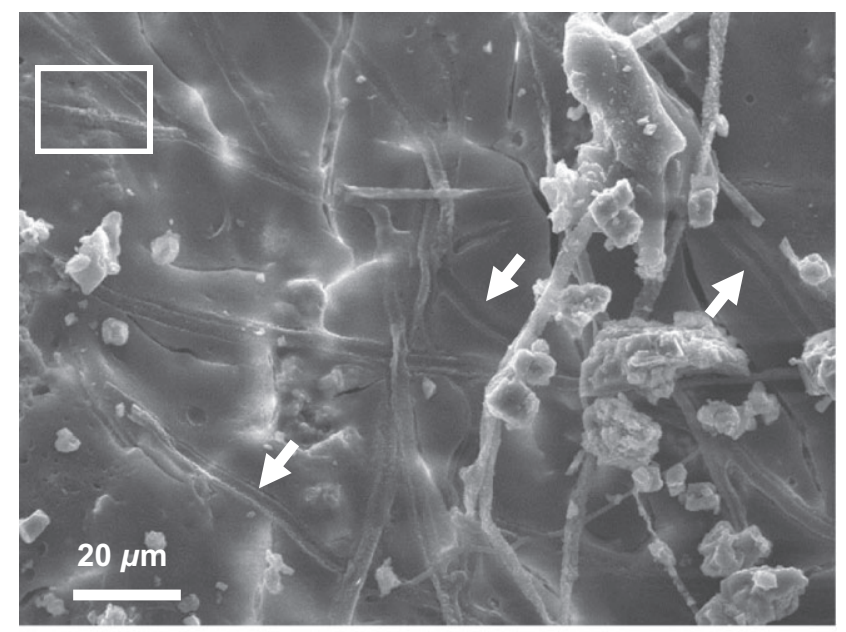

(b)

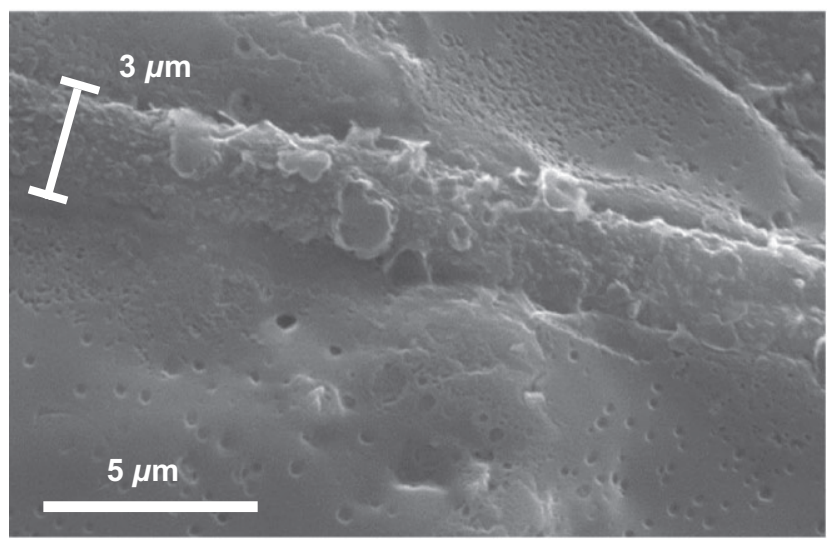

Figure 4. (a) SEM images of hyphae growing across the surface of a dolomite grain buried under L. decidua. Arrows indicate possible channels where hyphae have either detached from the rock surface, or have deflated in situ. Area highlighted is enlarged in b. Close up of surface detail and hypha channelling on dolomite grain. Scale bar $=3 \mu \mathrm{m}$ and indicates typical diameter of an EM hypha. 


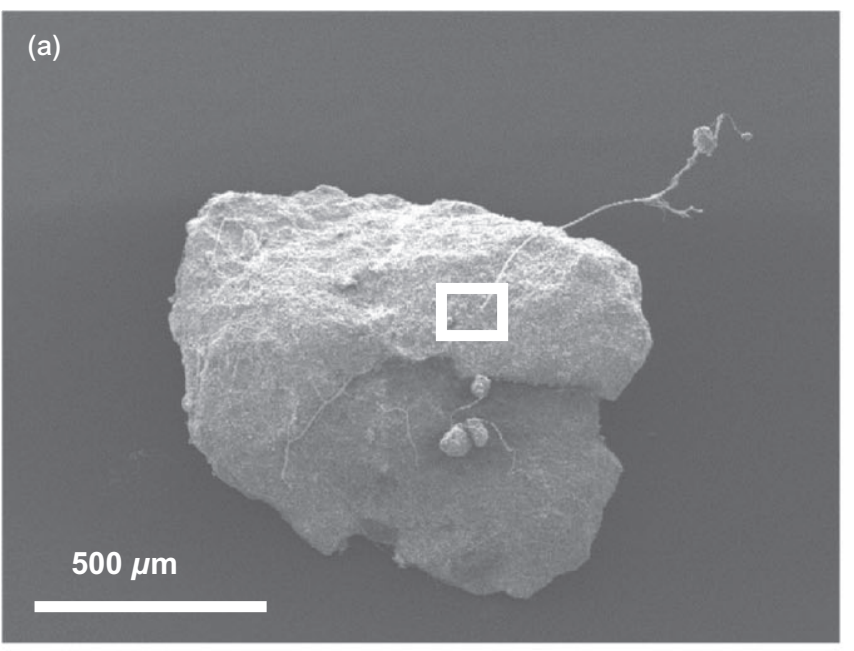

(b)
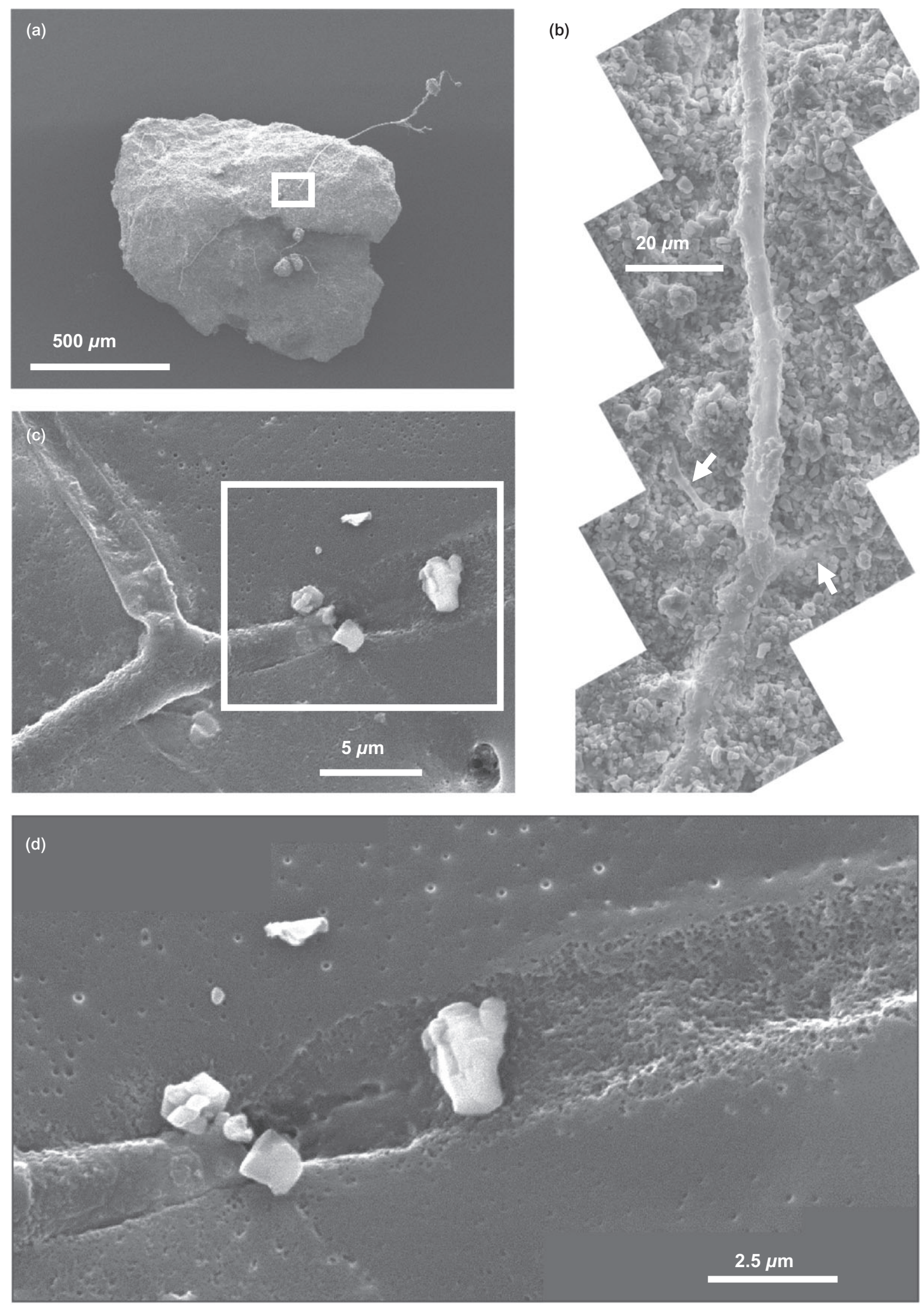

Figure 5. (a) SEM images of hyphae growing across the surface of a chalk grain buried under P. sylvestris. Area highlighted is enlarged in c. (b) Arrows indicate the location of smaller diameter branching hyphae. (c) Channelling by hypha on the surface of a dolomite grain buried under L. decidua, close-up of surface texture detail enlarged in d. 
vegetation-soil weathering interactions for arctic ecosystems. Beaulieu et al. (2012) reported a detailed modelling analysis of silicate and carbonate rock weathering in the Arctic Mackenzie River Basin watershed, in response to an increase in the atmospheric $\mathrm{CO}_{2}$ concentration from 355 to $560 \mathrm{ppm}$ and associated climate changes. Their model predicted an increase in bicarbonate export from carbonate weathering by $18 \%$ and from silicates by $40 \%$, with watershed bicarbonate flux from carbonate dissolution remaining an order of magnitude higher than that from silicate weathering. However, climate change predicted for the Mackenzie watershed is greater than the global average change, and other studies predict that $\mathrm{CO}_{2}$-driven intensification of weathering may be less dramatic. Earlier modelling work of Beaulieu et al. (2010) estimated a much smaller, 2.4-5\%, increase in silicate weathering per $100 \mathrm{ppm}$ rise in atmospheric $\mathrm{CO}_{2}$ since 1850 , across a range of catchments spanning different lithologies and climatic zones. Goll et al. (2014) predicted a $13 \%$ increase in global chemical weathering per $100 \mathrm{ppm} \mathrm{CO}_{2}$ over the same period, yet also demonstrated that there is still much uncertainty relating to $\mathrm{CO}_{2}$-driven weathering intensification. Weathering responses to elevated $\mathrm{pCO}_{2}$ vary spatially, and the magnitude and global pattern of responses is model dependent. Increases in the weathering-derived bicarbonate flux at elevated $\mathrm{CO}_{2}$ are related to changes in runoff and temperature, $\mathrm{CO}_{2}$-fertilization of vegetation net primary production (DeLucia et al. 1999) and to higher rates of autotrophic and heterotrophic respiration (Allen et al. 2000; Andrews \& Schlesinger 2001).

The direct effects of elevated $\mathrm{CO}_{2}$ on plants can affect soil hydrology, through partial stomatal closure reducing transpiration and improving water use efficiency (reviewed in Ainsworth \& Rogers 2007). As a consequence, soil drainage is increased, along with removal rate of weathering products, thus maintaining Eqn 1 in disequilibrium. This is supported by modelling results of Godderis et al. (2013) that predict changes in soil drainage will be the most important factor affecting dolomite weathering in the Mississippi valley, if $\mathrm{CO}_{2}$ were to increase from $315-700$ ppm over the period 1950 2100. Dissolution of dolomite responds linearly to drainage, as the equilibrium of carbonate alkalinity is maintained (Eqn 1). Overall, in the modelled watershed, $\mathrm{CO}_{2}$ consumption from carbonate weathering is predicted to decrease, over the period $1950-2100$, mainly because of a $4{ }^{\circ} \mathrm{C}$ temperature increase, as the solubility of dolomite, and other carbonate rocks, decreases with temperature (Godderis et al. 2013).

Few studies have investigated the responses of mineral weathering to increasing atmospheric $\mathrm{CO}_{2}$ concentrations experimentally. However, in the Duke FACE (free-air $\mathrm{CO}_{2}$ enrichment) experiment, loblolly pine trees ( $P$. taeda L.) were fumigated with $\mathrm{CO}_{2}$ elevating atmospheric concentrations above ambient by 200 ppm for over 2 years and soil mineral weathering responses quantified. Both autotrophic and heterotrophic respiration, and associated soil $\mathrm{CO}_{2}$ concentrations, increased over this period, leading to a corresponding decrease in soil $\mathrm{pH}$. Increased soil acidity provided a more favourable environment for dissolution of carbonates and other minerals (Andrews \& Schlesinger 2001), and resulted in a $271 \%$ increase in soil cation concentration, increased soil alkalinity and 33\% higher flux of dissolved inorganic carbon within groundwater. Studies of mycorrhizas in the Duke forest showed that EM fungi proliferated with host trees exposed to $\mathrm{CO}_{2}$ fertilization. However, there was no increased investment in AM fungi of understorey vegetation or AM saplings including Acer rubrum (Garcia et al. 2008). Although the Duke FACE site overlies clay-rich soil derived from igneous silicate rock, a similar but potentially more dramatic increase in weathering may be expected for carbonate-containing soils. This is due to the strong dependence of carbonate weathering on carbonic acid (Eqns 1, 5), and their faster weathering kinetics. Overall, modelling studies and field experiments illustrate a variety of weathering responses to increasing atmospheric $\mathrm{CO}_{2}$. These range from greatly accelerated carbonate dissolution, right through to decreased weathering rates in some catchments. Future carbonate weathering responses are likely to be highly heterogeneous, depending on the precise combination of vegetation, geology, soil drainage and climate change within each watershed, making this a critical area for future research.

\section{CONCLUSIONS}

Temperate and boreal forest ecosystems overlie much carbonate lithology, particularly in the Northern Hemisphere and historical land use changes are already exerting substantial effects on carbonate rock weathering rates and landocean alkalinity fluxes. This review shows that there are plausible physical and chemical mechanisms involving mycorrhizal fungi that could accelerate carbonate rock weathering within forest soils. Evidence from our ongoing field study at the UK's national pinetum confirms a wide range of mature EM and AM angiosperm and gymnosperm tree species increase the weathering rates of carbonate rocks. Preliminary results for 3 months rock incubation (MayAugust 2013) show differences in calcite and dolomite weathering rates when exposed to different tree and mycorrhizal functional groups. Especially rapid weathering is observed within EM angiosperm forest soils. The cause of these observed differences requires further investigation, but in line with theoretical expectations, soil $\mathrm{pH}$ appears to be a central factor in determining carbonate dissolution rates. Within our field trial, we also observed direct interactions between fungal hyphae and weathering rock grains within EM forest soils. These interactions act to alter mineral surface topography and increase weatherable surface area through fungal trenching and pitting at the hyphal-mineral interface. Fungal channelling is likely to result from a combination of physical, chemical and enzymatic weathering mechanisms, and future studies of these features may help improve understanding of the fine-scale mechanisms of fungal carbonate weathering.

More broadly, our findings are relevant to enhancing carbonate weathering, $\mathrm{CO}_{2}$ sequestration and potential amelioration of surface ocean acidification. Our analyses suggest strategic planting of suitable tree-mycorrhizal plant func- 
tional groups, such as notable fast-growing EM angiosperm taxa, might offer a possibility for utilizing weathering as a natural ecosystem service to accelerate these effects.

\section{ACKNOWLEDGMENTS}

We would like to thank Dr Joe Quirk and Dr David Johnson for help with fieldwork and Daniel Luscombe, curator at Bedgebury National Pinetum, Forestry Commission England. Rocks were donated by Pisani Matlock, The Dolomite Quarry, Doncaster and W.Clifford Watts Ltd, Bridlington. This project was supported by the E-Futures Doctoral Training Centre, and funded by EPSRC. We gratefully acknowledge funding of Lyla. L. Taylor through an ERC advanced grant to D.J.B (CDREG, 32998).

\section{REFERENCES}

Ainsworth E.A. \& Rogers A. (2007) The response of photosynthesis and stomatal conductance to rising $\left[\mathrm{CO}_{2}\right]$ : mechanisms and environmental interactions. Plant, Cell \& Environment 30, 258-270.

Allen A.S., Andrews J.A., Finzi A.C., Matamala R., Richter D.D. \& Schlesinger W.H. (2000) Effects of free-air CO2 enrichment (FACE) on belowground processes in a Pinus taeda forest. Ecological Applications 10, 437-448.

Amiotte-Suchet P., Probst J.-L. \& Ludwig W. (2003) Worldwide distribution of continental rock lithology: implications for the atmospheric/soil $\mathrm{CO}_{2}$ uptake by continental weathering and alkalinity river transport to the oceans. Global Biogeochemical Cycles 17, 1038-1051.

Andrews J.A. \& Schlesinger W.H. (2001) Soil $\mathrm{CO}_{2}$ dynamics, acidification, and chemical weathering in a temperate forest with experimental $\mathrm{CO}_{2}$ enrichment. Global Biogeochemical Cycles 15, 149-162.

Arocena J.M., Glowa K.R. \& Massicotte H.B. (2001) Calcium-rich hypha encrustations on Piloderma. Mycorrhiza 10, 209-215.

Arvieu J.C., Leprince F. \& Plassard C. (2003) Release of oxalate and protons by ectomycorrhizal fungi in response to P-deficiency and calcium carbonate in nutrient solution. Annals of Forest Science 60, 815-821.

Balogh-Brunstad Z., Keller C.K., Dickinson J.T., Stevens F., Li C.Y. \& Bormann B.T. (2008) Biotite weathering and nutrient uptake by ectomycorrhizal fungus, Suillus tomentosus, in liquid-culture experiments. Geochimica et Cosmochimica Acta 72, 2601-2618.

Beaulieu E., Godderis Y., Labat D., Roelandt C., Oliva P. \& Guerrero B. (2010) Impact of atmospheric $\mathrm{CO}_{2}$ levels on continental silicate weathering. Geochemistry Geophysics Geosystems 11, 1-18.

Beaulieu E., Godderis Y., Donnadieu Y., Labat D. \& Roelandt C. (2012) High sensitivity of the continental-weathering carbon dioxide sink to future climate change. Nature Climate Change 2, 346-349.

Beerling D.J. \& Royer D.L. (2011) Convergent Cenozoic $\mathrm{CO}_{2}$ history. Nature Geoscience 4, 418-420.

Berner R.A. (1992) Weathering, plants and the long-term carbon cycle. Geochimica et Cosmochimica Acta 56, 3225-3231.

Berner R.A. (2003) The long-term carbon cycle, fossil fuels and atmospheric composition. Nature 426, 323-326.

Berner R.A., Lasaga A.C. \& Garrels R.M. (1983) The carbonate-silicate geochemical cycle and its effect on atmospheric carbon dioxide over the past 100 million years. American Journal of Science 283, 641-683.

Blum J.D., Klaue A., Nezat C.A., Driscoll C.T., Johnson C.E., Siccama T.G. \& Likens G.E. (2002) Mycorrhizal weathering of apatite as an important calcium source in base-poor forest ecosystems. Nature 417, 729-731.

Bonneville S., Smits M.M., Brown A., Harrington J., Leake J.R., Brydson R. \& Benning L.G. (2009) Plant-driven fungal weathering: early stages of mineral alteration at the nanometer scale. Geology 37, 615-618.

Brantley S.L. \& Mellott N.P. (2000) Surface area and porosity of primary silicate minerals. American Mineralogist 85, 1767-1783.

Brantley S.L., Megonigal J.P., Scatena F.N., Balogh-Brunstad Z., Barnes R.T., Bruns M.A. \& Yoo K. (2011) Twelve testable hypotheses on the geobiology of weathering. Geobiology 9, 140-165.

Brook G.A., Folkoff M.E. \& Box E.O. (1983) A world model of soil carbon dioxide. Earth Surface Processes and Landforms 8, 79-88.
Cai W.-J., Hu X., Huang W.-J., Murrell M.C., Lehrter J.C., Lohrenz S.E., . . Gong G.-C. (2011) Acidification of subsurface coastal waters enhanced by eutrophication. Nature Geoscience 4, 766-770.

Casarin V., Plassard C., Souche G. \& Arvieu J.-C. (2003) Quantification of oxalate ions and protons released by ectomycorrhizal fungi in rhizosphere soil. Agronomie-Sciences des Productions Vegetales et de l'Environnement 23, 461-470.

Casarin V., Plassard C., Hinsinger P. \& Arvieu J.C. (2004) Quantification of ectomycorrhizal fungal effects on the bioavailability and mobilization of soil $\mathrm{P}$ in the rhizosphere of Pinus pinaster. New phytologist 163, 177 185.

Chou L., Garrels R.M. \& Wollast R. (1989) Comparative study of the kinetics and mechanisms of dissolution of carbonate minerals. Chemical Geology 78, 269-282.

DeLucia E.H., Hamilton J.G., Naidu S.L., Thomas R.B., Andrews J.A., Finzi A.C. \& Schlesinger W.H. (1999) Net primary production of a forest ecosystem with experimental $\mathrm{CO}_{2}$ enrichment. Science 284, 1177-1179.

Diaz R.J. \& Rosenberg R. (2008) Spreading dead zones and consequences for marine ecosystems. Science 321, 926-929.

Dürr H.H., Meybeck M. \& Dürr S.H. (2005) Lithologic composition of the Earth's continental surfaces derived from a new digital map emphasizing riverine material transfer. Global Biogeochemical Cycles 19, GB4S10.

Gadd G.M. \& Poole R.K. (1999) Fungal production of citric and oxalic acid: importance in metal speciation, physiology and biogeochemical processes. Advances in Microbial Physiology 41, 47-92.

Gaillardet J., Dupré B., Louvat P. \& Allègre C.J. (1999) Global silicate weathering and $\mathrm{CO}_{2}$ consumption rates deduced from the chemistry of large rivers. Chemical Geology 159, 3-30.

Garcia M.O., Ovasapyan T., Greas M. \& Treseder K.K. (2008) Mycorrhizal dynamics under elevated $\mathrm{CO}_{2}$ and nitrogen fertilization in a warm temperate forest. Plant and Soil 303, 301-310.

Gazzè S.A., Saccone L., Ragnarsdottir K.V., Smits M.M., Duran A.L., Leake J.R., ... McMaster T.J. (2012) Nanoscale channels on ectomycorrhizalcolonized chlorite: evidence for plant-driven fungal dissolution. Journal of Geophysical Research-Biogeosciences 117, G00N09.

Gislason S.R., Oelkers E.H., Eiriksdottir E.S., Kardjilov M.I., Gisladottir G., Sigfusson B. \& Oskarsson N. (2009) Direct evidence of the feedback between climate and weathering. Earth and Planetary Science Letters 277, 213-222.

Godderis Y., Brantley S.L., Francois L.M., Schott J., Pollard D., Deque M. \& Dury M. (2013) Rates of consumption of atmospheric $\mathrm{CO}_{2}$ through the weathering of loess during the next $100 \mathrm{yr}$ of climate change. Biogeosciences 10, 135-148.

Goll D.S., Moosdorf N., Hartmann J. \& Brovkin V. (2014) Climate-driven changes in chemical weathering and associated phosphorus release since 1850: implications for the land carbon balance. Geophysical Research Letters 41, 3553-3558.

GraphPad (2014) GraphPad Prism version 6.04 for Windows. GraphPad Software, La Jolla California, USA.

Hartmann J., Jansen N., Duerr H., Kempe S. \& Koehler P. (2009) Global $\mathrm{CO}_{2}$-consumption by chemical weathering: what is the contribution of highly active weathering regions? Global and Planetary Change 69, 185 194.

Hartmann J., West A.J., Renforth P., Koehler P., De La Rocha C.L., Wolf-Gladrow D.A., . . . Scheffran J. (2013) Enhanced chemical weathering as a geoengineering strategy to reduce atmospheric carbon dioxide, supply nutrients, and mitigate ocean acidification. Reviews of Geophysics 51, 113 149.

Hartmann J., Moosdorf N., Lauerwald R., Hinderer M. \& West A.J. (2014) Global chemical weathering and associated P-release - The role of lithology, temperature and soil properties. Chemical Geology 363, 145163.

Haselwandter K. (2008) Structure and function of siderophores produced by mycorrhizal fungi. Mineralogical Magazine 72, 61-64.

van Hees P.A.W., Jones D.L. \& Godbold D.L. (2002) Biodegradation of low molecular weight organic acids in coniferous forest podzolic soils. Soil Biology \& Biochemistry 34, 1261-1272.

van Hees P.A.W., Godbold D.L., Jentschke G. \& Jones D.L. (2003) Impact of ectomycorrhizas on the concentration and biodegradation of simple organic acids in a forest soil. European Journal of Soil Science 54, 697-706.

Hoffland E., Giesler R., Jongmans A.G. \& Breemen N. (2003) Feldspar tunelling by fungi along natural productivity gradients. Ecosystems 6, 739_ 746. 
Hoppert M., Flies C., Pohl W., Gänzl B. \& Schneider J. (2004) Colonization strategies of lithobiontic microorganisms on carbonate rocks. Environmental Geology 46, 421-428.

IPCC (2013) Climate change 2013: the physical science basis - summary for policymakers. Cambridge University Press.

IPCC (2014) Climate change 2014: impacts, adaptation, and vulnerability IPCC WGII AR5 summary for policymakers. Cambridge University Press.

Koele N., Dickie I., Blum J., Gleason J. \& de Graaf L. (2014) Ecological significance of mineral weathering in ectomycorrhizal and arbuscular mycorrhizal ecosystems from a field-based comparison. Soil Biology and Biochemistry 69, 63-70.

Kolo K., Keppens E., Preat A. \& Claeys P. (2007) Experimental observations on fungal diagenesis of carbonate substrates. Journal of Geophysical Research-Biogeosciences 112, G01007.

Landeweert R., Hoffland E., Finlay R.D., Kuyper T.W. \& van Breemen N. (2001) Linking plants to rocks: ectomycorrhizal fungi mobilize nutrients from minerals. Trends in Ecology \& Evolution 16, 248-254.

Lapeyrie F., Chilvers G.A. \& Bhem C.A. (1987) Oxalic acid synthesis by the mycorrhizal fungus Paxillus involutus. New Phytologist 106, 139-146.

Leake J.R., Duran A.L., Hardy K.E., Johnson I., Beerling D.J., Banwart S.A. \& Smits M.M. (2008) Biological weathering in soil: the role of symbiotic root-associated fungi biosensing minerals and directing photosynthateenergy into grain-scale mineral weathering. Mineralogical Magazine $\mathbf{7 2}$, 85-89.

Li W., Yu L.J., Yuan D.X., Wu Y. \& Zeng X.D. (2005) A study of the activity and ecological significance of carbonic anhydrase from soil and its microbes from different karst ecosystems of Southwest China. Plant and Soil 272, 133-141.

Li W., Zhou P.-P., Jia L.-P., Yu L.-J., Li X. \& Zhu M. (2009) Limestone dissolution induced by fungal mycelia, acidic materials, and carbonic anhydrase from fungi. Mycopathologia 167, 37-46.

Li Y.H. (1982) A brief discussion on the mean oceanic residence time of elements. Geochimica et Cosmochimica Acta 46, 2671-2675.

Lian B., Yuan D. \& Liu Z. (2011) Effect of microbes on karstification in karst ecosystems. Chinese Science Bulletin 56, 3743-3747.

Liu Z., Dreybrodt W. \& Liu H. (2011) Atmospheric $\mathrm{CO}_{2}$ sink: silicate weathering or carbonate weathering? Applied Geochemistry 26, S292-S294.

Liu Z.H. (2001) Role of carbonic anhydrase as an activator in carbonate rock dissolution and its implication for atmospheric CO2 sink. Acta Geologica Sinica (English Edition) 75, 275-278.

Liu Z.H., Yuan D.X. \& Dreybrodt W. (2005) Comparative study of dissolution rate-determining mechanisms of limestone and dolomite. Environmental Geology 49, 274-279.

Manning D.A.C. \& Renforth P. (2013) Passive sequestration of atmospheric $\mathrm{CO}_{2}$ through coupled plant-mineral reactions in urban soils. Environmental Science \& Technology 47, 135-141.

Marschner H. (ed.) (1995) Mineral Nutrition of Higher Plants, 2nd edn. Academic Press, London, UK.

Navarre-Sitchler A. \& Brantley S. (2007) Basalt weathering across scales Earth and Planetary Science Letters 261, 321-334.

Nowotny I., Schwanz J. \& Rothe G.M. (1998) Influence of soil acidification and liming on selected enzymes of the carbohydrate metabolism and the contents of two major organic acids of mycorrhizal roots of Norway spruce (Picea abies L. Karst. Plant and Soil 199, 41-51.

Ovington J.D. (1953) Studies of the development of woodland conditions under different trees. 1. Soils pH. Journal of Ecology 41, 13-34.

Palandri J. \& Kharaka Y. (2004) A compilation of rate parameters of watermineral interaction kinetics for application to geochemical modelling. Open file report 2004-1068.

Perrin A.-S., Probst A. \& Probst J.-L. (2008) Impact of nitrogenous fertilizers on carbonate dissolution in small agricultural catchments: implications for weathering $\mathrm{CO}_{2}$ uptake at regional and global scales. Geochimica et Cosmochimica Acta 72, 3105-3123.

Quirk J., Beerling D.J., Banwart S.A., Kakonyi G., Romero-Gonzalez M.E. \& Leake J.R. (2012) Evolution of trees and mycorrhizal fungi intensifies silicate mineral weathering. Biology Letters 8, 1006-1011.

Raymond P.A. \& Cole J.J. (2003) Increase in the export of alkalinity from North America's largest river. Science 301, 88-91.

Raymond P.A., Oh N.H., Turner R.E. \& Broussard W. (2008) Anthropogenically enhanced fluxes of water and carbon from the Mississippi river. Nature 451, 449-452.

Read D.J. (1991) Mycorrhizas in ecosystems. Experientia 47, 376-391.
Read D.J., Leake J.R. \& Perez-Moreno J. (2004) Mycorrhizal fungi as drivers of ecosystem processes in heathland and boreal forest biomes. Canadian Journal of Botany-Revue Canadienne De Botanique 82, 12431263.

Renforth P., Manning D.A.C. \& Lopez-Capel E. (2009) Carbonate precipitation in artificial soils as a sink for atmospheric carbon dioxide. Applied Geochemistry 24, 1757-1764.

Renforth P., Washbourne C.L., Taylder J. \& Manning D.A.C. (2011) Silicate production and availability for mineral carbonation. Environmental Science \& Technology 45, 2035-2041.

Renshaw J.C., Robson G.D., Trinci A.P.J., Wiebe M.G., Livens F.R., Collison D. \& Taylor R.J. (2002) Fungal siderophores: structures, functions and applications. Mycological Research 106, 1123-1142.

Ronov A. (1968) Probable changes in the composition of sea water during the course of geological time. Sedimentology 10, 25-43.

Rosling A. (2003) Responses of Ectomycorrhizal Fungi to Mineral Substrates. Swedish University of Agricultural Sciences, Uppsala, Sweden.

Rosling A., Lindahl B.D. \& Finlay R.D. (2004a) Carbon allocation to ectomycorrhizal roots and mycelium colonising different mineral substrates. New Phytologist 162, 795-802.

Rosling A., Lindahl B.D., Taylor A.F.S. \& Finlay R.D. (2004b) Mycelial growth and substrate acidification of ectomycorrhizal fungi in response to different minerals. FEMS Microbiology Ecology 47, 31-37.

Saccone L., Gazze S.A., Duran A.L., Leake J.R., Banwart S.A., Ragnarsdottir K.V., . . McMaster T.J. (2012) High resolution characterization of ectomycorrhizal fungal-mineral interactions in axenic microcosm experiments. Biogeochemistry 111, 411-425.

Sandnes A., Eldhuset T.D. \& Wollebaek G. (2005) Organic acids in root exudates and soil solution of Norway spruce and silver birch. Soil Biology \& Biochemistry 37, 259-269.

Schmalenberger A., Duran A.L., Romero-Gonzales M.E., Leake J.R. \& Banwart S.A. (2010) Oxalic acid release in ectomycorrhiza mineral weathering. Geochimica et Cosmochimica Acta 74, A923.

van Scholl L., Hoffland E. \& van Breemen N. (2006a) Organic anion exudation by ectomycorrhizal fungi and Pinus sylvestris in response to nutrient deficiencies. New Phytologist 170, 153-163.

van Scholl L., Smits M.M. \& Hoffland E. (2006b) Ectomycorrhizal weathering of the soil minerals muscovite and hornblende. New Phytologist 171, 805814.

Scholle P. \& Ulmer-Scholle D. (2003) A Color Guide to the Petrography of Carbonate Rocks: Grains, Textures, Porosity, Diagenesis. American Association of Petroleum Geologists, Tulsa, OK, USA.

Scoffin T.P. (1987) An Introduction to Carbonate Sediments and Rocks. Blackie, Glasgow and London, UK.

Smits M.M., Hoffland E., Jongmans A.G. \& van Breemen N. (2005) Contribution of mineral tunneling to total feldspar weathering. Geoderma 125, 59-69.

Smits M.M., Bonneville S., Benning L.G., Banwart S.A. \& Leake J.R. (2012) Plant-driven weathering of apatite - the role of an ectomycorrhizal fungus. Geobiology 10, 445-456.

Szaniszlo P.J., Powell P.E., Reid C.P.P. \& Cline G.R. (1981) Production of hydroxamate siderophore iron chelators by ectomycorrhizal fungi. Mycologia 73, 1158-1174.

Tans P. \& Keeling R. (2013) Mauna Loa $\mathrm{CO}_{2}$ monthly mean data. NOAA/ ESRL, Scripps Institution of Oceanography.

Taylor L.L., Leake J.R., Quirk J., Hardy K., Banwart S.A. \& Beerling D.J. (2009) Biological weathering and the long-term carbon cycle: integrating mycorrhizal evolution and function into the current paradigm. Geobiology $\mathbf{7}$, 171-191.

Tisserant E., Kohler A., Dozolme-Seddas P., Balestrini R., Benabdellah K., Colard A. \& Martin F. (2012) The transcriptome of the arbuscular mycorrhizal fungus Glomus intraradices (DAOM 197198) reveals functional tradeoffs in an obligate symbiont. New Phytologist 193, 755-769.

Toljander J.F., Lindahl B.D., Paul L.R., Elfstrand M. \& Finlay R.D. (2007) Influence of arbuscular mycorrhizal mycelial exudates on soil bacterial growth and community structure. FEMS Microbiology Ecology 61, 295-304.

USGS (2008) Global land cover characteristics data base version 2.0. US Department of the Interior, US Geological Survey.

Verrecchia E.P. \& Dumont J.L. (1996) A biogeochemical model for chalk alteration by fungi in semiarid environments. Biogeochemistry 35, 447-470.

Wallander H. \& Thelin G. (2008) The stimulating effect of apatite on ectomycorrhizal growth diminishes after PK fertilization. Soil Biology \& Biochemistry 40, 2517-2522. 
West T.O. \& McBride A.C. (2005) The contribution of agricultural lime to carbon dioxide emissions in the United States: dissolution, transport, and net emissions. Agriculture Ecosystems \& Environment 108, 145-154.

White A.F. \& Brantley S.L. (2003) The effect of time on the weathering of silicate minerals: why do weathering rates differ in the laboratory and field? Chemical Geology 202, 479-506.

Wickham H. (2009) ggplot2: Elegant Graphics for Data Analysis. Springer, New York, NY, USA.
Williams P. \& Fong Y.T. (2010) World map of carbonate rock outcrops v3.0. School of Environment, University of Auckland.

Zeebe R.E. (2012) History of seawater carbonate chemistry, atmospheric $\mathrm{CO}_{2}$, and ocean acidification. Annual Review of Earth and Planetary Sciences 40, $141-165$.

Received 21 May 2014; accepted for publication 18 August 2014 